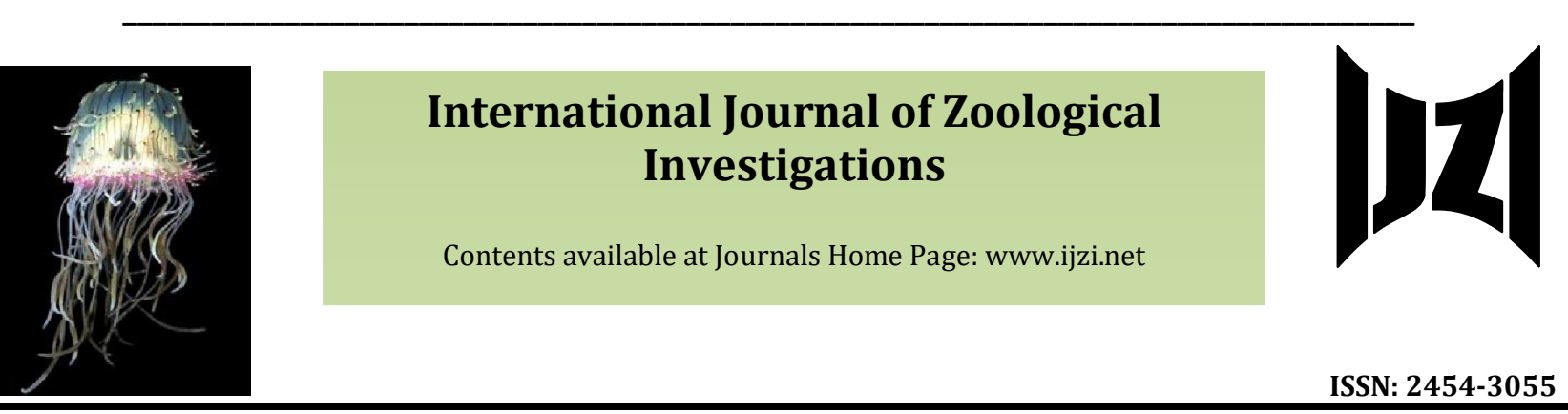

\title{
Production of Worm Biomass (Vermiprotein) and Vermicompost by Using Epigeic Earthworms
}

\author{
Patil Soumya R. and Biradar Pulikeshi M.* \\ Department of Zoology, Karnatak University, Dharwad-580003, India \\ *Corresponding Author
}

Received: $13^{\text {th }}$ October, 2019

Accepted: 27th November, 2019

$\underline{\text { https://doi.org/10.33745/ijzi.2019.v05i02.007 }}$

\begin{abstract}
Epigeic earthworms are known to convert variety of organic wastes into useful products such as vermicompost, worm biomass and vermiwash. The present study was undertaken to know the potentiality of epigeic earthworms (Eudrilus eugeniae, Eisenia fetida and Perionyx excavatus) in bio-processing of organic wastes for the production of worm biomass and vermicompost. Observations were made with respect to initial and final biomass of worms, biomass ratio, fold increase in worm number, per cent compost and vermicompost at various time intervals (30, 60 and 90 days) produced out of three epigeic earthworms. The gross biomass, biomass ratio and fold increase in worm number significantly $(\mathrm{P}<0.05)$ varies with respect to different earthworms and at 30,60 and 90days time intervals. As the days increases (30,60 and 90 days), the gross biomass, biomass ratio, fold increase in worm number, per cent compost and vermicompost were also increased over the time in all three species. The maximum worm biomass, fold increase in worm number and per cent vermicompost were noticed in cultures of E. eugeniae followed by E. fetida and P. excavatus. The per cent vermicompost produced was directly proportional and positively correlated with gross biomass and fold increase in worm number over the time from 30 , 60 and 90 days in all three species. Hence, all three variety of epigeic earthworms can effectively be used in the production of quantity and quality worm biomass and vermicompost for pharmaceutical use and sustainable agricultural practices, respectively.
\end{abstract}

Keywords: Epigeic earthworms, Worm biomass, Compost, Vermicompost

Citation: Patil Soumya R. and Biradar Pulikeshi M.: Production of worm biomass (vermiprotein) and vermicompost by using epigeic earthworms.. Intern. J. Zool. Invest. 5 (2): 85-96, 2019.

https://doi.org/10.33745/ijzi.2019.v05i02.007

\section{Introduction}

Earthworms contribute significantly in managing various organic wastes for the production of useful products like vermicompost and worm biomass. Effective recycling of different organic wastes is a novel work towards organic waste management and 
tackling many environmental problems (Ansari and Hanief, 2015). Earthworm's transfers unavailable nutrients present in the organic matter of wastes into available forms necessary for plant growth through the process of mineralization by the help of saprophytic microorganisms present in the gut of earthworms (Ansari and Hanief, 2015).

Vermitechnology is one of the valuable methods of converting organic wastes into useful products like vermicompost, worm biomass and vermiwash by using specialized epigeic and anecic earthworm species. The production of vermicompost and worm biomass varies with respect to different types of earthworms, food type and prevailing environmental conditions etc.

Vermicomposting by different species of earthworms have been undertaken by various researchers using different organic wastes such as sewage sludge (Mitchell, 1977), pig manure (Chan and Griffiths, 1988), cotton industrial wastes (Albanell et al., 1988), industrial and vegetable wastes (Bano et al., 1987) and paper mill wastes (Butt, 1993) etc. Vermicomposting is not only used as an alternative source of production of organic fertilizers, but it also provides economical animal feed protein in the form of worm biomass for fish and poultry industries (Edwards, 1985; Kale, 2000).

The organic wastes generated in agricultural fields and gardens are abundant that are creating serious disposal problems and are the major sources of environmental pollution (Inbar et al., 1993). All these wastes can be utilized as raw materials in vermitechnology for the production of vermicompost as well as worm biomass. Hence, the present study was undertaken to know the potentiality of different epigeic earthworms in production of worm biomass and per cent vermicompost cultured in cattle manure at various time intervals in uncontrolled room environmental conditions.

\section{Materials and Methods}

Collection of food and preparation of culture beds:

Sufficient quantity of urine free cattle manure (CM) was brought, sun dried, powdered and is used for experimental purpose. The powdered cattle manure (CM) was sprayed with tap water in order to get moisture content of about $75-80 \%$ and kept it for a week for initiation of microbial degradation.

Selection of suitable earthworm species:

The selection of appropriate species of earthworm for vermicomposting is very important based on the adaptability to waste, minimal gut transit time, fast growth rate and high reproductive potential rate are some of the important qualities which must be present in earthworm species. At present, Eudrilus eugeniae (EE), Eisenia fetida (EF) and Perionyx excavatus (PE) earthworms are used in our studies as these worms are voracious feeder and breeder throughout the year, extensively used for biodegradation of organic wastes and its management so as to produce valuable vermicompost and worm biomass for further use for different purposes.

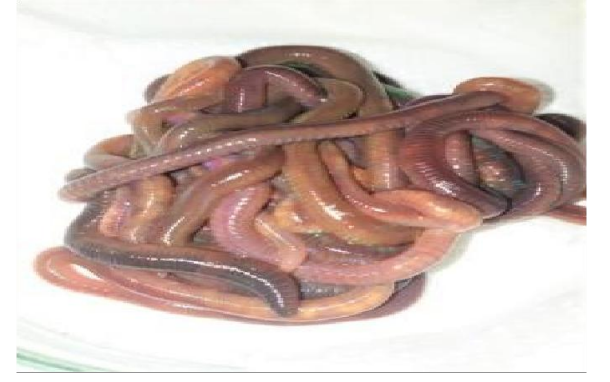

Eudrilus eugeniae 


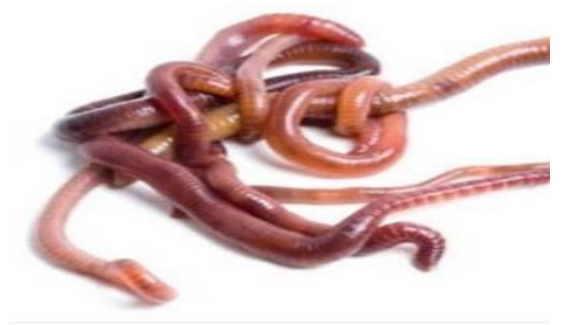

Eisenia fetida

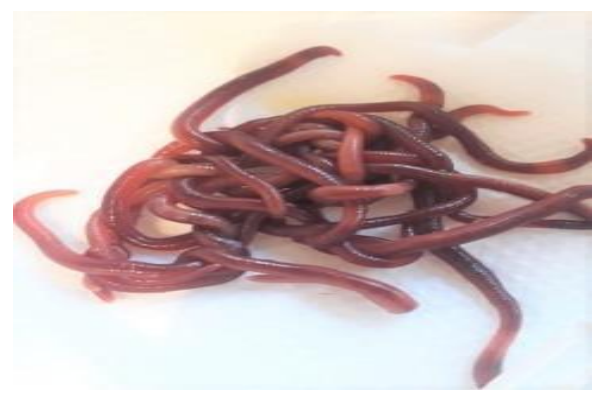

Perionyx excavatus

Inoculation of earthworms:

Five sexually matured all three epigeic earthworms were isolated separately from stock culture and inoculated in each experimental culture pots after noting their weight. Simultaneously, to know the role of earthworms in vermicomposting, another set without earthworms served as control (compost) was maintained and per cent compost was also calculated at 30, 60 and 90 days time intervals.

All culture containers of composts and vermicomposts of three different earthworm species at 30, 60 and 90 days time intervals in triplicates were maintained with sufficient food with daily sprinkling of required amount of tap water to import $70-75 \%$ moisture in uncontrolled room environmental conditions.

\section{Termination of experiments:}

All the experiments were terminated after 30 , 60 and 90 days time intervals. Observations were made with respect to number of old and new adult worms, subclitellets, juveniles, cocoons and their weight to determine the worm biomass, biomass ratio and fold increase in worm number.

Gross biomass was calculated by adding weight of all new individuals of different stages including cocoons at the end of experiment gained by initial five inoculated adult worms. Biomass ratio increased from initial weight to final weight and fold increase in worm number from initial worms were also calculated. Per cent compost and vermicompost produced at the end of each experiments (30, 60 and 90 days) were also calculated by isolating degraded materials with the help of $0.2 \mathrm{~mm}$ sieve.

\section{Statistical analysis:}

Statistical analysis of the data and correlation co-efficient were carried out through ANOVA and Pearson's correlation test, respectively by SPSS programme.

\section{Results and Discussion}

Results of the present study with respect to production of gross biomass, biomass ratio, fold increase in worm number, per cent compost and vermicompost produced by three different epigeic earthworm species at 30, 60 and 90 days time intervals were represented in the Table 1.

\section{Worm biomass:}

The gross biomass, biomass ratio and fold increase in worm number of all three species increased drastically from 30, 60 and 90 days time intervals (Table 1). There is a positive correlation with increase in gross biomass, biomass ratio and fold increase in worm with number of days (30,60 and 90 days) as the number of days increases, the gross biomass, fold increase in worm number also increases from 30 to 90 days periods. The mean gross 
biomass of Eudrilus eugeniae, Eisenia fetida and Perionyx excavatus are $7.47 \pm 0.17$, $13.75 \pm 0.66,18.34 \pm 0.30 ; 3.95 \pm 0.00,8.57 \pm 0.33$, $11.39 \pm 0.48$ and $1.39 \pm 0.04,2.78 \pm 0.03$ and $4.79 \pm 0.32$ at 30,60 and 90 days, respectively (Table 1; Fig. 1). Similarly, the biomass ratio is $1: 1.79 \pm 0.30,1: 3.29 \pm 0.14$ and $1: 4.60 \pm 0.16$; $1: 1.97 \pm 0.00,1: 4.18 \pm 0.15$ and $1: 5.32 \pm 0.21$ and $1: 1.42 \pm 0.04, \quad 1: 2.97 \pm 0.02$ and $1: 5.13 \pm 0.38$ from initial weight to final weight (Table 1; Fig. 2). There is a drastic increase in fold increase in worm number from initially inoculated earthworms at 30,60 and 90 days which are $8.66 \pm 0.33,21.00 \pm 0.57$ and
$39.33 \pm 1.76 ; \quad 5.66 \pm 0.33, \quad 13.00 \pm 0.57$ and $26.00 \pm 1.76$ and $2.66 \pm 0.33,11.66 \pm 0.57$ and $19.33 \pm 2.18$ in Eudrilus eugeniae, Eisenia fetida and Perionyx excavatus, respectively (Table 1; Fig. 3). The maximum gross biomass and fold increase in worm number are noticed in Eudrilus eugeniae $\quad(18.34 \pm 0.30 \quad$ and $39.33 \pm 1.76)$ followed by Eisenia fetida $(11.39 \pm 0.48$ and $26.00 \pm 1.76)$ and Perionyx excavatus $(4.79 \pm 0.32$ and $19.33 \pm 2.18)$, whereas biomass ratio is more in EF $\quad(1: 5.32 \pm 0.21) \quad$ followed by PE $(1: 5.13 \pm 0.38)$ and EE (1: 4.60 \pm 0.16$)$ cultured in cattle manure at 90 days period.

Table 1: Gross biomass, biomass ratio, fold increase in worm number and per cent compost and vermicompost produced by three epigeic earthworms at various time intervals $(30,60$, and 90 days $)$ cultured in cattle manure and their significant value $(\mathrm{P}<0.05)$ among different species

\begin{tabular}{|c|c|c|c|c|c|c|c|}
\hline \multirow{2}{*}{$\begin{array}{l}\text { SI. } \\
\text { No. }\end{array}$} & \multirow{2}{*}{$\begin{array}{c}\text { Earthworm } \\
\text { species }\end{array}$} & \multirow{2}{*}{$\begin{array}{c}\text { Periods } \\
\text { (days) }\end{array}$} & \multicolumn{5}{|c|}{ Parameters } \\
\hline & & & $\begin{array}{c}\text { Gross } \\
\text { biomass }\end{array}$ & $\begin{array}{c}\text { Biomass } \\
\text { ratio } \\
\text { (IW:GBW) }\end{array}$ & FIWN & $\begin{array}{c}\% \\
\text { Vermicompost }\end{array}$ & $\begin{array}{c}\% \\
\text { Compost }\end{array}$ \\
\hline \multirow{3}{*}{1} & \multirow{3}{*}{$\begin{array}{l}\text { Eudrilus } \\
\text { eugeniae }\end{array}$} & 30 & $7.47 \pm 0.17$ & $1: 1.79 \pm 0.03$ & $8.66 \pm 0.33$ & $61.66 \pm 1.66$ & $24.50 \pm 0.28$ \\
\hline & & 60 & $13.75 \pm 0.66$ & $1: 3.29 \pm 0.14$ & $21.00 \pm 0.57$ & $100 \pm 0.00$ & $33.83 \pm 1.01$ \\
\hline & & 90 & $18.34 \pm 0.30$ & $1: 4.60 \pm 0.16$ & $39.33 \pm 1.76$ & $100 \pm 0.00$ & $53.50 \pm 0.76$ \\
\hline \multirow{3}{*}{2} & \multirow{3}{*}{$\begin{array}{l}\text { Eisenia } \\
\text { fetida }\end{array}$} & 30 & $3.95 \pm 0.00$ & $1: 1.97 \pm 0.00$ & $5.66 \pm 0.33$ & $43.33 \pm 1.66$ & $24.50 \pm 0.28$ \\
\hline & & 60 & $8.57 \pm 0.33$ & $1: 4.18 \pm 0.15$ & $13.00 \pm 0.57$ & $68.33 \pm 1.66$ & $33.83 \pm 1.01$ \\
\hline & & 90 & $11.39 \pm 0.48$ & $1: 5.32 \pm 0.21$ & $26.00 \pm 1.76$ & $90.00 \pm 0.00$ & $53.50 \pm 0.76$ \\
\hline \multirow{3}{*}{3} & \multirow{3}{*}{$\begin{array}{l}\text { Perionyx } \\
\text { excavatus }\end{array}$} & 30 & $1.39 \pm 0.04$ & $1: 1.42 \pm 0.04$ & $2.66 \pm 0.33$ & $35.00 \pm 0.00$ & $24.50 \pm 0.28$ \\
\hline & & 60 & $2.78 \pm 0.03$ & $1: 2.97 \pm 0.02$ & $11.66 \pm 0.57$ & $65.00 \pm 0.00$ & $33.83 \pm 1.01$ \\
\hline & & 90 & $4.79 \pm 0.32$ & $1: 5.13 \pm 0.38$ & $19.33 \pm 2.18$ & $75.00 \pm 0.00$ & $53.50 \pm 0.76$ \\
\hline 4 & \multicolumn{2}{|c|}{ F-value } & $\mathrm{F}=274.14$ & $\mathrm{~F}=73.19$ & $F=97.18$ & $\mathrm{~F}=573.83$ & $F=388.00$ \\
\hline 5 & \multicolumn{2}{|c|}{ P-value } & $\mathrm{P}=0.00$ & $\mathrm{P}=0.00$ & $\mathrm{P}=0.00$ & $\mathrm{P}=0.00$ & $\mathrm{P}=0.00$ \\
\hline
\end{tabular}

Data are in Mean \pm SE

IW: Initial weight, GBW: Gross biomass weight, FIWN: Fold increase in worm number 


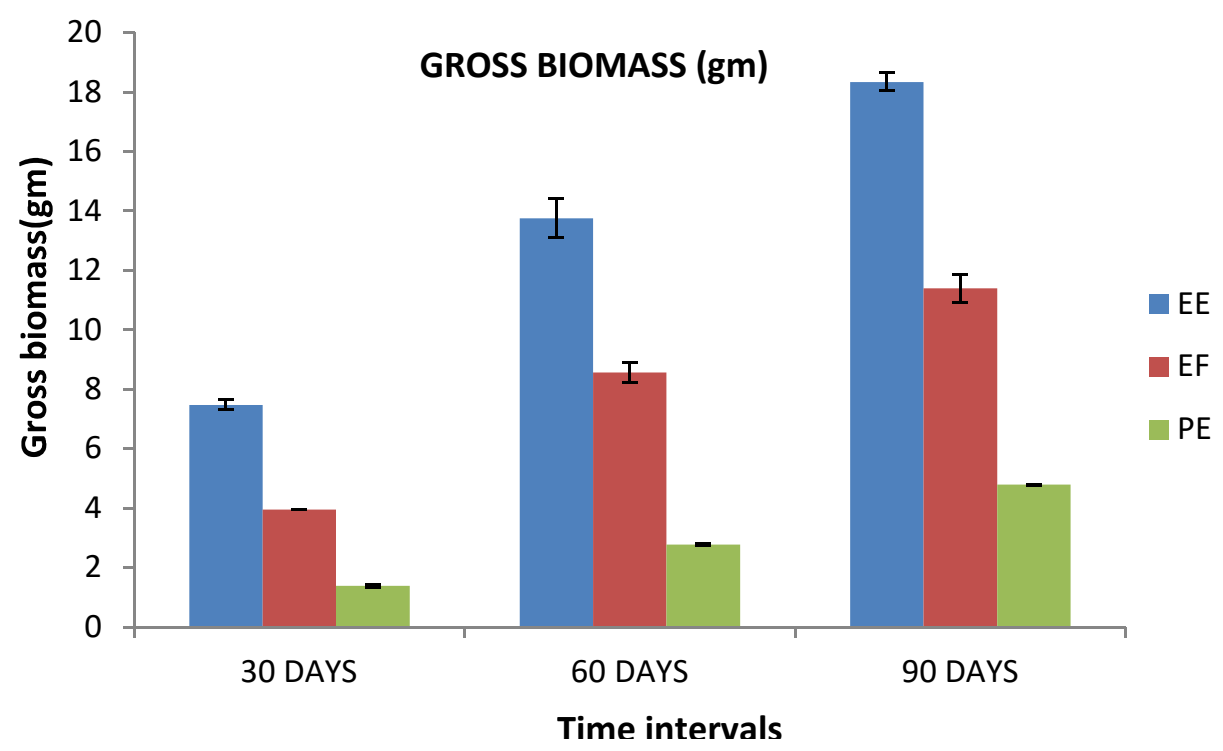

Fig. 1: Gross biomass (Mean \pm SE) produced by different epigeic earthworms at various time intervals $(30,60$ and 90 days)

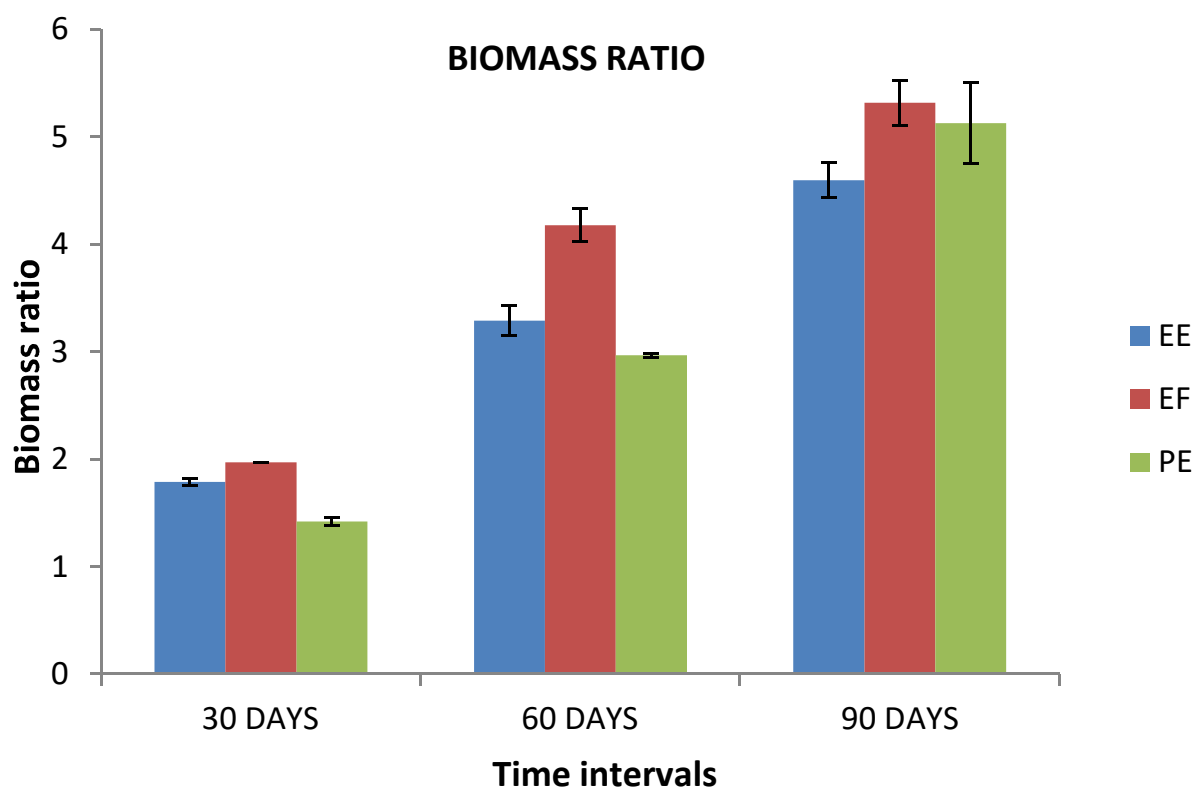

Fig. 2: Biomass ratio (Mean \pm SE) observed in different epigeic earthworms at various time intervals $(30,60$ and 90 days) 


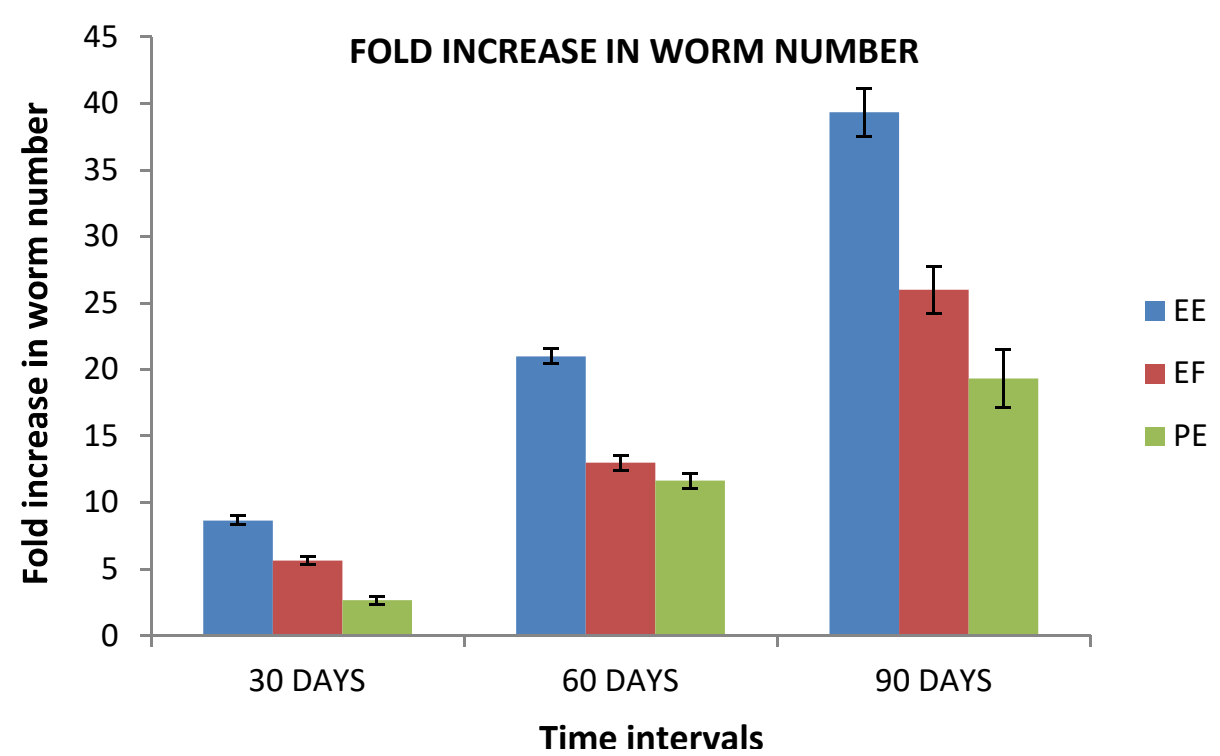

Fig. 3: Fold increase in worm number (FIWN) by different epigeic earthworms at various time intervals $(30,60$ and 90 days $)$

Results revealed that there is a significant difference in gross biomass, biomass ratio and fold increase in worm number among all three species at different time intervals $(30,60,90$ days) (Table 1). There is no significant variation in gross biomass between 30 days EF and 90 days PE and between 30 and 60 days PE (Table 2). Similarly, there is no significant difference in biomass ratio between 30 and 90 days EE and 30 and 60 days EF, respectively. Whereas no significant variation is observed in FIWN between 30 days $\mathrm{EE}$ and $\mathrm{EF}$ and 30 and 60 days of EE and 60 and 90 days $\mathrm{PE}$, respectively and also between 30 and 60 days EF and 30 and 60 days $P E$, respectively (Table 2 ).

There is a drastic variation in the gross biomass, biomass ratio and fold increase in worm number between different epigeic earthworm species at various time intervals (30, 60 and 90 days). It was more in EE followed by EF and PE, this variation may be due to difference in their feeding and breeding habit, growth pattern, life cycle, adjustment to available food materials, individual reproductive capability and congenial environmental conditions etc.

Reinecke et al. (1992) and Viljoen and Reinecke (1994) have noticed variations in growth rate and cocoon production with respect to different earthworm species and also with different organic wastes, EE, EF and PE cultured in cow dung for a total period of one year increased at the rate of 12 $\mathrm{mg} /$ worm/day, $7 \mathrm{mg} /$ worm/day and 3.5 mg/worm/day, respectively. Kale and Krishnamoorthy (1981) have reported that the nature of available food source influences worm activity. Likewise, Reinecke and Venter (1985) have also noticed increase in worm biomass with the feeding activities of the worms. Suthar (2011) studied biomass growth pattern in Allolobophora parva and noticed that there is a consistent trend of rapid biomass increase up to $13^{\text {th }}$ weeks, thereafter a marked gradual decline in individual biomass.

The quality and palatability of food directly affect the survival, growth rate and reproductive potentiality of earthworms 
Table 2: Significant variation $(\mathrm{P}<0.05)$ between gross biomass, biomass ratio, fold increase in worm number and \% compost and vermicompost produced by different epigeic earthworms cultured in cattle manure at various time intervals $(30,60$ and 90 days)

\section{Gross biomass:}

\begin{tabular}{|c|c|c|c|c|c|c|c|c|c|c|}
\hline \multirow[t]{2}{*}{ Earthworm species } & \multirow[b]{2}{*}{ Time } & \multicolumn{3}{|c|}{ Eudrilus eugeniae } & \multicolumn{3}{|c|}{ Eisenia fetida } & \multicolumn{3}{|c|}{ Perionyx excavatus } \\
\hline & & 30 & 60 & 90 & 30 & 60 & 90 & 30 & 60 & 90 \\
\hline \multirow[t]{3}{*}{ Eudrilus eugeniae } & 30 & - & 0.00 & 0.00 & 0.00 & 0.03 & 0.00 & 0.00 & 0.00 & 0.00 \\
\hline & 60 & 0.00 & - & 0.00 & 0.00 & 0.00 & 0.00 & 0.00 & 0.00 & 0.00 \\
\hline & 90 & 0.00 & 0.00 & - & 0.00 & 0.00 & 0.00 & 0.00 & 0.00 & 0.00 \\
\hline \multirow{3}{*}{ Eisenia fetida } & 30 & 0.00 & 0.00 & 0.00 & - & 0.00 & 0.00 & 0.00 & 0.02 & 0.09 \\
\hline & 60 & 0.03 & 0.00 & 0.00 & 0.00 & - & 0.00 & 0.00 & 0.00 & 0.00 \\
\hline & 90 & 0.00 & 0.00 & 0.00 & 0.00 & 0.00 & - & 0.00 & 0.00 & 0.00 \\
\hline \multirow{3}{*}{ Perionyx excavatus } & 30 & 0.00 & 0.00 & 0.00 & 0.00 & 0.00 & 0.00 & - & 0.09 & 0.00 \\
\hline & 60 & 0.00 & 0.00 & 0.00 & 0.02 & 0.00 & 0.00 & 0.09 & - & 0.00 \\
\hline & 90 & 0.00 & 0.00 & 0.00 & 0.09 & 0.00 & 0.00 & 0.00 & 0.00 & - \\
\hline
\end{tabular}

\section{Biomass ratio:}

\begin{tabular}{|c|c|c|c|c|c|c|c|c|c|c|}
\hline \multirow[t]{2}{*}{ Earthworm species } & \multirow[b]{2}{*}{ Time } & \multicolumn{3}{|c|}{ Eudrilus eugeniae } & \multicolumn{3}{|c|}{ Eisenia fetida } & \multicolumn{3}{|c|}{ Perionyx excavatus } \\
\hline & & 30 & 60 & 90 & 30 & 60 & 90 & 30 & 60 & 90 \\
\hline \multirow{3}{*}{ Eudrilus eugeniae } & 30 & - & 0.00 & 0.00 & 0.47 & 0.00 & 0.00 & 0.14 & 0.00 & 0.00 \\
\hline & 60 & 0.00 & - & 0.00 & 0.00 & 0.00 & 0.00 & 0.00 & 0.20 & 0.00 \\
\hline & 90 & 0.00 & 0.00 & - & 0.00 & 0.10 & 0.00 & 0.00 & 0.00 & 0.04 \\
\hline \multirow{3}{*}{ Eisenia fetida } & 30 & 0.47 & 0.00 & 0.00 & - & 0.00 & 0.00 & 0.03 & 0.00 & 0.00 \\
\hline & 60 & 0.00 & 0.00 & 0.10 & 0.00 & - & 0.00 & 0.00 & 0.00 & 0.00 \\
\hline & 90 & 0.00 & 0.00 & 0.00 & 0.00 & 0.00 & - & 0.00 & 0.00 & 0.46 \\
\hline \multirow{3}{*}{ Perionyx excavatus } & 30 & 0.14 & 0.00 & 0.00 & 0.03 & 0.00 & 0.00 & - & 0.00 & 0.00 \\
\hline & 60 & 0.00 & 0.20 & 0.00 & 0.00 & 0.00 & 0.00 & 0.00 & - & 0.00 \\
\hline & 90 & 0.00 & 0.00 & 0.04 & 0.00 & 0.00 & 0.46 & 0.00 & 0.00 & - \\
\hline
\end{tabular}


3. Fold increase in worm number (FIWN):

\begin{tabular}{|c|c|c|c|c|c|c|c|c|c|c|}
\hline Earthworm species & \multicolumn{6}{|c|}{ Eudrilus eugeniae } & \multicolumn{3}{|c|}{ Eisenia fetida } & \multicolumn{3}{c|}{ Perionyx excavatus } \\
\hline & Time & 30 & 60 & 90 & 30 & 60 & 90 & 30 & 60 & 90 \\
\hline \multirow{4}{*}{ Eudrilus eugeniae } & 30 & - & 0.00 & 0.00 & 0.08 & 0.01 & 0.00 & 0.00 & 0.17 & 0.00 \\
\cline { 2 - 11 } & 60 & 0.00 & - & 0.00 & 0.00 & 0.00 & 0.00 & 0.00 & 0.00 & 0.32 \\
\cline { 2 - 12 } & 90 & 0.00 & 0.00 & - & 0.00 & 0.00 & 0.00 & 0.00 & 0.00 & 0.00 \\
\hline \multirow{5}{*}{ Eisenia fetida } & 30 & 0.08 & 0.00 & 0.00 & - & 0.00 & 0.00 & 0.08 & 0.00 & 0.00 \\
\cline { 2 - 11 } & 60 & 0.01 & 0.00 & 0.00 & 0.00 & - & 0.00 & 0.00 & 0.24 & 0.00 \\
\cline { 2 - 11 } & 90 & 0.00 & 0.00 & 0.00 & 0.00 & 0.00 & - & 0.00 & 0.00 & 0.00 \\
\hline \multirow{3}{*}{ Perionyx excavatus } & 30 & 0.00 & 0.00 & 0.00 & 0.08 & 0.00 & 0.00 & - & 0.00 & 0.00 \\
\cline { 2 - 10 } & 60 & 0.17 & 0.00 & 0.00 & 0.00 & 0.24 & 0.00 & 0.00 & - & 0.00 \\
\cline { 2 - 10 } & 90 & 0.00 & 0.32 & 0.00 & 0.00 & 0.00 & 0.00 & 0.00 & 0.00 & - \\
\hline
\end{tabular}

\section{Per cent compost and vermicompost:}

\begin{tabular}{|c|c|c|c|c|c|c|c|c|c|c|c|c|c|}
\hline \multirow{2}{*}{$\begin{array}{l}\text { Earthworm } \\
\text { species }\end{array}$} & & \multicolumn{3}{|c|}{ Eudrilus eugeniae } & \multicolumn{3}{|c|}{ Eisenia fetida } & \multicolumn{3}{|c|}{ Perionyx excavatus } & \multicolumn{3}{|c|}{ Compost } \\
\hline & Time & 30 & 60 & 90 & 30 & 60 & 90 & 30 & 60 & 90 & 30 & 60 & 90 \\
\hline \multirow{3}{*}{$\begin{array}{l}\text { Eudrilus } \\
\text { eugeniae }\end{array}$} & 30 & - & 0.00 & 0.00 & 0.00 & 0.00 & 0.00 & 0.00 & 0.02 & 0.00 & 0.00 & 0.00 & 0.00 \\
\hline & 60 & 0.00 & - & 1.00 & 0.00 & 0.00 & 0.00 & 0.00 & 0.00 & 0.00 & 0.00 & 0.00 & 0.00 \\
\hline & 90 & 0.00 & 1.00 & - & 0.00 & 0.00 & 0.00 & 0.00 & 0.00 & 0.00 & 0.00 & 0.00 & 0.00 \\
\hline \multirow{3}{*}{$\begin{array}{l}\text { Eisenia } \\
\text { fetida }\end{array}$} & 30 & 0.00 & 0.00 & 0.00 & - & 0.00 & 0.00 & 0.00 & 0.00 & 0.00 & 0.00 & 0.00 & 0.00 \\
\hline & 60 & 0.00 & 0.00 & 0.00 & 0.00 & - & 0.00 & 0.00 & 0.02 & 0.00 & 0.00 & 0.00 & 0.00 \\
\hline & 90 & 0.00 & 0.00 & 0.00 & 0.00 & 0.00 & - & 0.00 & 0.00 & 0.00 & 0.00 & 0.00 & 0.00 \\
\hline \multirow{3}{*}{$\begin{array}{l}\text { Perionyx } \\
\text { excavatus }\end{array}$} & 30 & 0.00 & 0.00 & 0.00 & 0.00 & 0.00 & 0.00 & - & 0.00 & 0.00 & 0.00 & 0.38 & 0.00 \\
\hline & 60 & 0.02 & 0.00 & 0.00 & 0.00 & 0.02 & 0.00 & 0.00 & - & 0.00 & 0.00 & 0.00 & 0.00 \\
\hline & 90 & 0.00 & 0.00 & 0.00 & 0.00 & 0.00 & 0.00 & 0.00 & 0.00 & - & 0.00 & 0.00 & 0.00 \\
\hline
\end{tabular}


(Suthar, 2009, 2010). Kale and Krishnamoorthy (1978) have also reported that each species of earthworms have different preferences towards organic matter among various wastes. The cocoon production was affected by various food sources as the cumulative cocoon number was increased in Perionyx excavatus with the increase in the age of food substrates (Birundha et al., 2013).

Swatti and Vikram Reddy (2010) have observed that the net individual weight and the total biomass gain were higher in PE compared to that of EF and EE in Market waste (MW) and Floral waste (FW). Ranganathan and Parthasarathi (1999) reported that the kind and amount of food materials available will influence the size of the earthworm population, species diversity, growth and fecundity. They also mentioned that earthworms require food rich in nitrogen, cellulose and microorganisms for their growth and reproduction.

\section{Per cent compost and vermicompost:}

The per cent compost and vermicompost produced were gradually increased from 30 , 60 and 90 days time intervals in all the experimental sets. The per cent compost produced at 30, 60 and 90 days is $24.50 \%$, $33.83 \%$ and $53.50 \%$, respectively. Likewise, per cent vermicompost produced by Eudrilus eugeniae, Eisenia fetida and Perionyx excavatus are 61.66, 100 and 100; 43.33, 68.33 and $90.00 \%$ and $35.00,65.00$ and $75.00 \%$, respectively.

There is a significant variation between and among normal per cent compost and vermicompost produced by different epigeic earthworms (Table 1, Fig. 4) at various time intervals. Among per cent vermicompost, there is no significant difference between 60 and 90 days of EE and between 30 days PE-VC and 60 days normal compost (Table 2).

The $\%$ vermicompost produced was positively correlated or directly proportional with gross biomass of worms and fold increase in worm number over the time from 30,60 , and 90 day's time intervals cultured in cattle manure as this is known to be the best food for epigeic earthworms (Table 3).

Vermicomposting is a process of stabilization of organic material involving the joint action of earthworms and microorganisms, wherein microbes are responsible for biochemical degradation of organic matter, while, earthworms are important drivers of vermicomposting process, conditioning the substrate and altering the biological activity (Aira et al., 2002)

Production of per cent vermicompost was comparatively more in all three epigeic earthworm species than that of normal per cent compost at different time intervals; this may be due to the presence of earthworms and their feeding activities. Feeding activities of earthworms and microorganisms present in the gut may decrease the time of stabilization of organic wastes and produced value added vermicompost in the form of organic fertilizer.

Vermicomposting through earthworms is an eco-biotechnological process that transforms energy rich and complex organic substance into a stabilized end product called vermicompost (Benitez et al., 2000). Gosh et al. (1999) expressed the usage of epigeic earthworms in vermicomposting process and it has increased the production of a better quality of vermicompost significantly as 
Table 3: Pearson's correlation co-efficient between gross biomass (GB) and fold increase in worm number (FIWN) and per cent vermicompost (VC) produced by different epigeic earthworms

\begin{tabular}{|c|c|c|c|}
\hline Particulars & EE-VC & EF-VC & PE-VC \\
\hline EE-GB & +0.907 & - & - \\
\hline EF-GB & - & +0.995 & - \\
\hline PE-GB & - & - & +0.919 \\
\hline EE-FIWN & +0.805 & - & - \\
\hline EF-FIWN & - & +0.994 & - \\
\hline PE-FIWN & - & - & +0.973 \\
\hline
\end{tabular}

GB-Gross biomass, FIWN-Fold increase in worm number, VC: vermicompost

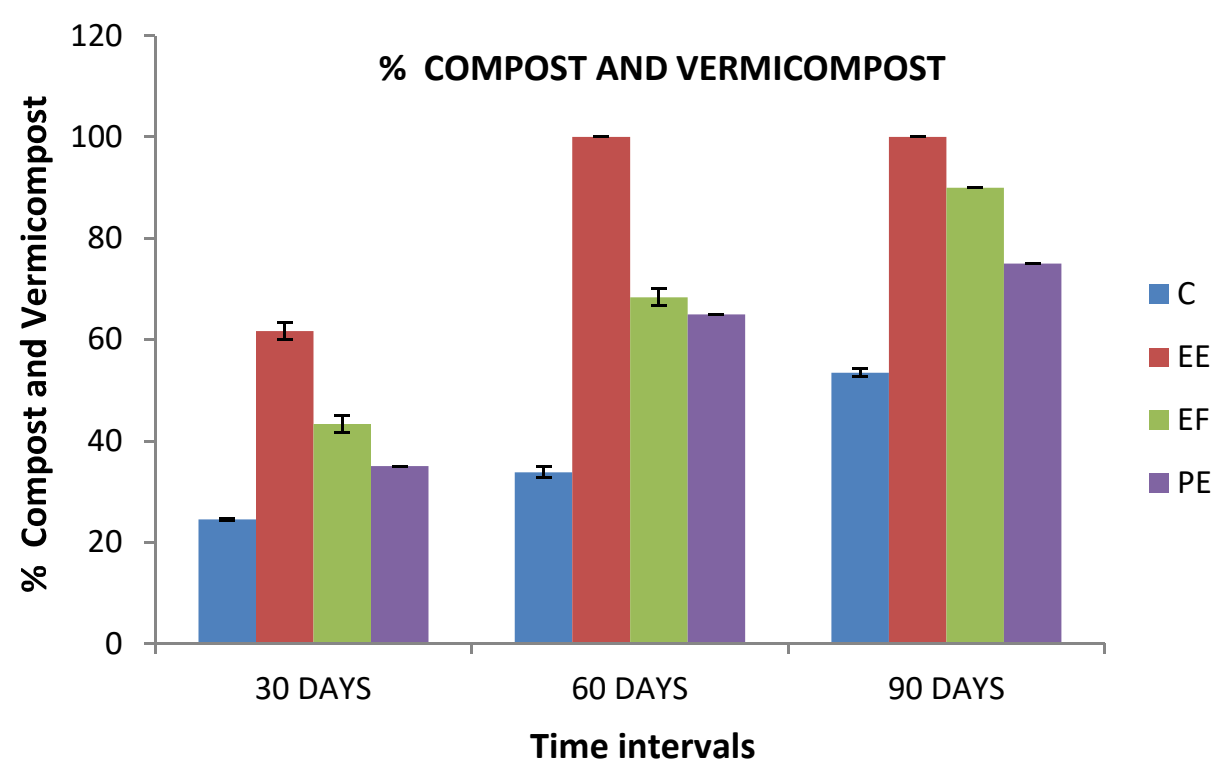

Fig. 4: Per cent compost and vermicompost produced by different epigeic earthworms at various time intervals (30, 60 and 90 days) 
compared with those produced through traditional composting methods.

Compost and vermicompost are the end products of aerobic composting and vermicomposting process, among these, vermicompost possess higher and more soluble level of major nutrients (Bansal and Kapoor, 2000; Singh and Sharma, 2002; Reddy and Okhura, 2004).

Swatti and Vikram Reddy (2010) have recorded composting and vermicomposting of two wastes MW (Market waste) and FW(Floral waste), higher mass reduction of MW in the vermicompost processed by EE (75\%) followed by EF (63\%) and PE (50\%) as compared to that of compost (26\%), whereas in FW the mass reduction was higher (83\%) in vermicompost produced by $\mathrm{EE}, 67 \%$ by $\mathrm{EF}$, $56 \%$ in PE and only $30 \%$ in sole compost was observed.

The cow dung used as an inoculants in the vermicomposting process that enhances the quality of feeding resources by attracting earthworms and accelerated the breakdown of organic wastes resulting in the decrease of $\mathrm{C}: \mathrm{N}$ ratio by increasing certain nutrients (Kitturmath et al., 2007; Gupta and Garg, 2009).

\section{Conclusion}

Disposal and management of organic waste materials including dung is a serious issue in our country and the fertilizer values are not properly utilized resulting in the loss of many more nutrients. Vermitechnology is an ecobiotechnological process used to convert wide variety of organic wastes including animal dung through recycling and reutilization of precious organic wastes bringing about bioconversion and bio-vitalization of natural resources and would lead to aero waste technology.

\section{Acknowledgement}

The authors are thankful to the authorities of Karnatak University for providing necessary facilities to carry out this work at Department of Zoology, Karnatak University, Dharwad and UGC, New Delhi for financial support under SAP-DSA-I programme to carry out research work on Vermitechnology.

\section{References}

Aira M, Monroy F, Dominguez J and Mato S. (2002) How earthworm density affects microbial biomass and activity in pig mature. European Journal Soil Biology, 38: 7-10.

Albanell E, Plaixats J and Cabrero T. (1988) Chemical changes during vermicomposting (Eisenia fetida) of sheep manure mixed with cotton industrial wastes. Biology Fertility of Soils 6: 266-269.

Ansari AA and Hanief A. (2015) Microbial degradation of organic waste through vermicomposting. International J. Sustainable Agricultural Research 2: 45-54.

Bano K, Kale R D and Gajanan GN. (1987) Culturing of earthworms Eudrilus eugeniae for cast production and assessment of 'worm cast' as biofertilizer. J. Soil Biol. Ecol. 7: 98-104.

Bansal Sand Kapoor KK (2000) Vermicomposting of crop residues and cattle dung with Eisenia foetida, Bioresource Technology 73: 95-98.

Butt KR. (1993) Utilization of solid paper mill sludge and spent brewery yeast as a feed for soil-dwelling earthworms. Bioresource Technology 44: 105-107.

Benitez E, Nogales R, Masciandro G and Ceccanti B. (2000) Isolation by isoelectric focusing of humicurease complexes from earthworm (Eisenia fetida) processed sewage sludges. Biology Fertility Soils 31: 489-493.

Birundha M, John Paul JA and Mariappan P. (2013) Growth and reproduction of Perionyx excavatus in 
different organic wastes. Intern. J. Current Microbiology Applied Sci. 2: 28-35.

Chan PLS and Griffiths DA. (1988) The vermicomposting of pretreated pig manure. Biological Waste 24: 57-69.

Edwards C A. (1985) Production of feed protein from animal waste by earthworms. Philosophical Transactions Royal Society- B Biological Sciences 310: 299-307.

Ghosh M, Chattopadhyay GN and Baral K. (1999) Transformation of phosphorus during vermicomposting. Bioresource Technology 69: 149-154.

Gupta R and Garg VK. (2009) Vermiremediation and nutrient recovery of non-recyclable paper waste employing Eisenia fetida. J. Hazardous Materials 162: 430-439.

Inbar Y, Hadar Y and Chen Y. (1993) Recycling of cattle manure: The composting process and characterization of maturity. J. Environmental Quality 22: 857-863.

Kale R D and Krishnamoorthy R V. (1978) Distribution and abundance of earthworms in Bangalore. Proc. Indian Acad. Sci. 88B: 23-25.

Kale R D and Krishnamoorthy RV. (1981) Enrichment of soil fertility by earthworm activity. In: Progress in Soil Biology and Ecology in India, Veeresh G. K. (ed), University of Agricultural Sciences, Bangalore. Technical Series 37: 64-68.

Kale RD. (2000) An evaluation of the vermitechnology process for the treatment of agro, sugar and food processing wastes. In: Technology Approaches to Waste Management, Industrial Associationship of IIT, Madras, pp. 15-17.

Kitturmath MS, Giradd RS and Basavaraj B. (2007) Nutrient changes during earthworm, Eudrilus eugeniae (Kinberg) mediated vermicomposting of agro industrial wastes. Karnataka. J. Agricultural Sciences 20:653-654.

Mitchell D. (1977) Reply to Revusky. Animal Learning Behavior 5: 321-322.
Ranganathan LS and Parathasarathi K. (1999) Longevity of microbial and enzyme activity and their influence. European J. Soil Biol. 35:107-113.

Reddy MV and Ohkura K. (2004) Vermicomposting of rice-straw and its effects on sorghum growth. Tropical Ecology 45: 327-331.

Reinecke A J and Venter JM. (1985) The influence of moisture on the growth and reproduction of the compost worm, Eisenia fetida (Oligochaeta). Rev. Ecol. Biol. Sol. 22: 473-481.

Reinecke AJ, Viljoen SA and Saayman RJ. (1992) The suitability of Eudrilus eugeniae, Perionyx excavates and Eisenia foetida (Oligochaeta) for vermicomposting in Southern Africa in terms of their temperature requirement. Soil Biology Biochemistry 24: 1295-1307.

Singh A and Sharma S. (2002) Composting of a crop residue through treatment with microorganisms and subsequent vermicomposting. Bioresources Technology 85: 107-111.

Suthar S. (2009) Potential of Allolobophora parva (Oligochaeta) in vermicomposting. Bioresource Technology 100: 6422-6427.

Suthar S. (2010) Evidence of plant hormone like substances in vermiwash: An ecologically safe option of synthetic chemicals for sustainable farming. Ecological Engineering 36: 1089-1092.

Suthar S. (2011) Earthworm biodiversity in western and semiarid land of India. Environmentalist 31: 174-186.

Swatti P and Vikram R. (2010) Assessment of municipal solid waste management in Puducherry (Pondicherry), India. Resources Conservation Recycling 54: 512-520.

Viljoein S A and Reineck A J. (1994) The life cycle and reproduction of Eudrilus eugeniae under controlled environmental conditions. Intern. J. Res. Pharmacy Life Sciences 89:149-157. 